УДК 811.111'25:070(043.3)

DOI https://doi.org/10.26661/2414-1135-2021-83-37

\title{
ЗАГАЛЬНА ХАРАКТЕРИСТИКА ФАХОВОЇ МОВИ ВІЙСЬКОВОЇ СФЕРИ (НА МАТЕРІАЛІ АНГЛІЙСЬКОЇ МОВИ)
}

\author{
Федоренко С. В. \\ доктор педагогічних наук, професор, \\ професор кафедри теорії, практики та перекладу англійської мови \\ Національний технічний університет України \\ «Київський політехнічний інститут імені Ігоря Сікорського» \\ просп. Перемоги, 37, Київ, Украӥна \\ orcid.org/0000-0001-8517-9975 \\ s.fedorenko297@gmail.com
}

Бернадіна А. В.

студент магістратури

кафедри теорії, практики та перекладу англійської мови

Національний технічний університет Украйни

«Київський політехнічний інститут імені Ігоря Сікорського»

просп. Перемоги, 37, Київ, Украӥна

orcid.org/0000-0002-1966-8911

bernanbeli@ukr.net

Ключові слова: англомовна
військова фахова мова,
військова термінологія,
інтрапрофесійні жанри,
емочійно забарвлена лексика,
екстралінгвістичні чинники.

Стаття висвітлює лексико-семантичні й жанрові особливості сучасної англомовної військової фахової мови, яка в силу багатогранності військових знань характеризується міждисциплінарністю. Актуальність дослідження зумовлена стрімкою мілітаризацією суспільства на тлі військово-політичних реформ, спричинених загостренням збройних протистоянь світового масштабу, що слугує поштовхом до стрімкогорозвитку фахової мови військової сфери, а тому є важливим і цікавим матеріалом для вивчення. Зазначено, що завдяки специфічній комунікативно-функціональній спрямованості фахова мова військової сфери оперує в межах трьох функціональних стилів мови (офіційно-ділового, публіцистичного й наукового). 3 точки зору загальної типології професійного мовлення велика частина жанрів, закріплених за військовою сферою, стосується інтрапрофесійної комунікації, яка не виходить за межі професійної спільноти. Наголошено, що військова фахова мова отримує найбільший розвиток у періоди воєнних конфліктів під впливом низки екстралінгвістичних чинників, 3-поміж яких основними $\epsilon$ специфіка діяльності, ступінь участі в збройних конфліктах широких народних мас i, відповідно, ступінь трансформації способу життя всієї мовної спільноти під час таких конфліктів, соціальний тип воєнних конфліктів. Розглянуто інтрапрофесійні жанри у військовій фаховій мові, що розподіляються на: 1) ті, які зорієнтовані на розпредмечування (військова публіцистика, військово-наукова комунікація, військово-дидактична комунікація); 2) жанри регулятивного характеру (настанови, інструкції, накази, команди, розпорядження тощо). Окреслено специфічні риси спілкування в межах досліджуваної фахової мови, які відображаються в жорсткій структурі військової документації, жанрова належність якої визначається засобом зв'язку та рольовими аспектами. Схарактеризовано дві основні групи військової лексики в досліджуваній сфері (військово-прикладна термінологія, що охоплює офіційну/статутну й нестатутну термінологію, яка вживається в усному мовленні військовослужбовців і в деяких видах військової літератури, але не є офіційно прийнятою; та емоційно забарвлена лексика військової сфери. Розкрито специфіку вживання певних військових термінів з огляду на американський і британський військовий контекст. 


\title{
GENERAL CHARACTERISTICS \\ OF THE PROFESSIONAL LANGUAGE OF THE MILITARY SPHERE (ON THE MATERIAL OF THE ENGLISH LANGUAGE)
}

\author{
Fedorenko S. V. \\ Doctor of Pedagogical Sciences, Professor, \\ Professor at the Department of Theory, Practice and Translation of English \\ National Technical University of Ukraine \\ "Igor Sikorsky Kyiv Polytechnic Institute" \\ Peremohy Ave, 37, Kyiv, Ukraine \\ orcid.org/0000-0001-8517-9975 \\ s.fedorenko297@gmail.com \\ Bernadina A. V. \\ Master's Student at the Department of Theory, \\ Practice and Translation of English \\ National Technical University of Ukraine \\ "Igor Sikorsky Kyiv Polytechnic Institute" \\ Peremohy Ave, 37, Kyiv, Ukraine \\ orcid.org/0000-0002-1966-8911 \\ bernanbeli@ukr.net
}

Key words: English military professional language, military terminology, intraprofessional genres, emotionally colored vocabulary, extralinguistic factors.
The article highlights the lexical-semantic and genre features of modern English-language military professional language, which, due to the diversity of military knowledge, is characterized by interdisciplinarity. The relevance of the study is due to the rapid militarization of the society against the background of military-political reforms caused by the escalation of armed confrontations on the global scale, which serves as an impetus for the rapid development of military language, and therefore, is important and interesting material to study. It is noted that due to the specific communicative-functional orientation, the professional language of the military sphere operates within three functional styles of language (official, publicistic and scientific). From the point of view of the general typology of the professional language, most of the genres, assigned to the military sphere, concern intraprofessional communication, which does not go beyond the professional community. It is emphasized that the military professional language is rapidly developing during military conflicts under the influence of a number of extralinguistic factors, which are as follows: the specifics of activities, the degree of participation in armed conflicts of the masses and the degree of transformation of the way of living of the entire language community during such conflicts, the social type of military conflicts. Intra-professional genres in the military professional language are considered. They are divided into: 1) those that are focused on objectification (military journalism, military-scientific communication, military-didactic communication); 2) genres of regulatory nature (instructions, orders, commands, instructions, etc.). The distinctive features of the communication within the professional language under study are outlined, reflecting in the rigid structure of the military documentation, the genre of which is determined by the means of communication and role aspects. There are two main groups of the military vocabulary (military-applied terminology, which includes official/ statutory and non-statutory terminology; and emotionally colored vocabulary. The specifics of the use of the certain military terms in view of the American and British military context are revealed. 
Постановка проблеми. На початку XXI ст. на тлі глобальної нестабільності, викликаної різними військовими інтервенціями в країни мусульманського світу, переважно коаліціями західних країн у чолі з США, зростає інтерес до збройних сил США та їхніх союзників, передусім Сполученого Королівства й інших англомовних країн Британської Співдружності. Також у зв'язку з тотальною мілітаризацією суспільства, що посилюється внаслідок виникнення й загострення збройних конфліктів на світовому рівні загалом та в Україні зокрема, актуальною постає проблема дослідження розвитку фахової мови військової сфери. Інтерес до цієї проблеми викликаний також і тим фактом, що військові реалії проникають у повсякденне життя й побутують у спілкуванні не лише військових, а й пересічних громадян, пронизуючи мову багатьох сфер соціального життя та відображаючи нагальні проблеми, пов'язані з оборонною справою.

Звідси випливає актуальність теми, яка зумовлюється стрімкою мілітаризацією суспільства на тлі військово-політичних реформ, спричинених загостренням збройних протистоянь світового масштабу, що слугує поштовхом до стрімкого розвитку фахової мови військової сфери, а тому $\epsilon$ важливим і цікавим матеріалом для лінгвістичного дослідження.

Фахова військова мова неодноразово була об'єктом дослідження вітчизняних i зарубіжних лінгвістів, які вивчали питання, пов'язані зі шляхами та способами творення військових термінів (Дж. Алджео, Л.Б. Ткачова, В.В. Кондрашов та ін.), лінгвальними й екстралінгвальними аспектами формування та функціонування військової термінології (В.М. Шевчук, Т.Д. Михайленко та ін.), проблемами визначення військового сленгу та його перекладу (Г.О. Судзиловський, В.В. Балабін, П. Діксон та ін.), когнітивними чинниками функціонування військової лексики (І.В. Андрусяк, Г.А. Бучина, Л.М. Венедиктова та ін.).

Мета й завдання статті. Мета статті - висвітлити лексико-семантичні та жанрові аспекти функціонування сучасної англомовної військової фахової мови.

Реалізація цієї мети вимагає розв'язання таких завдань: 1) вивчити комунікативну-функціональну специфіку фахової мови військової сфери; 2) проаналізувати й узагальнити жанрові особливості військової фахової мови; 3) дослідити лексико-семантичні особливості англомовної військової фахової мови.

Предмет та об'єкт дослідження. Об'єкт дослідження - англомовна фахова мова військової сфери. Предметом дослідження слугують лексико-семантичні й жанрові особливості англомовної військової фахової мови.
Виклад основного матеріалу дослідження. Військова фахова мова як спеціальна мова обслуговує різні аспекти військової сфери. Завдяки специфічній комунікативно-функціональній спрямованості фахова мова військової сфери оперує в межах трьох функціональних стилів мови - офіційно-ділового, публіцистичного та наукового. Перевага одного із цих стилів змінюється відповідно до теми комунікації. У сфері військової діяльності виокремлюють специфічні варіанти різних комунікативних систем: військово-офіційний, військово-науковий, військово-публіцистичний, військово-художній, військовий арго, військово-історичний тощо [2]. Ця варіативність здебільшого спричинена специфічним предметом діяльності у військовій сфері. Цей предмет - війна, тобто збройний конфлікт, який є соціальною небезпекою як для суспільства загалом, так і для окремих людей зокрема, адже суспільство, яке виявляється втягнутим у війну або веде війну, починає висловлювати свої думки в специфічних для цього середовища мовних формах. При цьому більшість дослідників поділяє думку $[2 ; 3 ; 5 ; 10 ; 11]$, що ті зміни на лексичному рівні, які відбуваються у фаховій військовій мові під час збройних конфліктів, мають тимчасовий характер і з відновленням мирного життя в суспільстві виходять iз загального вжитку. Але ці новоутворення закріплюються мовною традицією у військовій професійній сфері спілкування.

В останні десятиліття створено чимало словників, які намагаються з'ясувати та зафіксувати пов'язану $з$ конкретними війнами лексику, що представлена не лише військовою термінологією, а й сленгом, який влучно характеризує кожну війну. Т.Е. Мюррей зазначає в праці про термінологію льотчиків морських винищувачів: «Вивчення спеціалізованої англійської мови засвідчило, що представники збройних сил ... особливо схильні до мовної творчості», чи то солдати, моряки чи льотчики $[10$, с. 126]. 3 приводу цього суголосними є думки В. Сілкетта, який стверджує, що сьогодні мало яка фахова мова може конкурувати зі спеціалізованою військовою мовою щодо «запозичення, копіювання та зміни лексики» $[11$, с. 13]. Військова фахова мова $є$ надзвичайно продуктивною, що підкріплюється твердженням Т.Е. Мюррея: «Кожна криза створює власний словниковий склад» [10, с. 126]. Британський лексикограф Дж. Айто [8] зазначає, що будь-які технічні досягнення або політичні події, у яких беруть участь військові, спонукають до створення нового словника. Це свого роду парадокс, проте війни, незважаючи на численні руйнування, мають генеративний вплив на розвиток фахової мови військової сфери. «Найбільш загальними тенденціями зміни 
в лексичній системі мови в періоди воєн будьякого типу $є$ активізація військової термінології в усіх функціонально-стилістичних різновидах мови; розвиток системи військової термінології; поява нових термінів, які називають нові денотати; зміна обсягу значень деяких слів спільної мови завдяки семантичним переносам (лексичним метафорам); поява неологізмів, запозичених 3 мови противника, часто 3 пейоративним значенням тощо» $[2$, с. 20$]$.

Таким чином, сьогодні загальновизнаним $\epsilon$ той факт, що військова фахова мова отримує найбільший розвиток у періоди воєнних конфліктів під впливом низки екстралінгвістичних факторів, 3-поміж яких основними є специфіка діяльності, ступінь участі в збройних конфліктах широких народних мас i, відповідно, ступінь трансформації способу життя всієї мовної спільноти під час таких конфліктів, соціальний тип воєнних конфліктів. Щодо специфіки діяльності у військовій професійній сфері, то вона полягає насамперед у тому, що ця діяльність розгортається в ситуації постійної небезпеки, у якій від швидкості й точності скерованих дій залежить життя кожного військового. Тому така специфіка діяльності впливає й на основні риси фахової військової комунікації (стислість, лаконічність, ясність і точність) [2]. Це виражається у використанні певних клішованих мовних форм у текстах різних жанрів військового професійного мовлення, які покликані регламентувати військову діяльність (накази, настанови, інструкції, статути тощо).

На переконання Н. Гарбовського й Е. Мішкурова [2], з точки зору загальної типології професійного мовлення велика частина жанрів, закріплених за військовою сферою, стосується інтрапрофесійної комунікації, тобто комунікації, що не виходить за межі професійної спільноти. Інтрапрофесійні жанри в аналізованій сфері розподіляються на два основні групи: 1) ті, які зорієнтовані на розпредмечування (військова публіцистика, військово-наукова комунікація, військово-дидактична комунікація (підручники, навчальні посібники 3 військової справи)); 2) жанри регулятивного характеру (настанови, інструкції, накази, команди, розпорядження тощо). Проміжну позицію займає жанр бойових статутів, який характеризується подвійною прагматичною метою, де мета оволодіння діяльністю поєднується з метою iï врегулювання. Низка жанрів, закріплених за комунікацією у військовій сфері, виявляє подібні риси з жанрами інших фахових мов. Це стосується насамперед військової публіцистики, військово-наукової та військово-дидактичної комунікації [2, с. 24].

Як стверджує Ю. Дуброва [3], специфічні риси спілкування в межах досліджуваної фахової мови відображаються в жорсткій структурі військової документації, жанрова належність якої визначається каналом зв'язку і статусно-рольовими аспектами. Щодо специфіки мови, то в англомовних військових документах, як правило, вживаються: перформативні іменники (order - наказ, instruction - розпорядження, directive - директива тощо); перформативні дієслова в теперішньому часі (to assign, to establish, to inform, to provide) та після модального дієслова shall, що виражає волю адресанта, наказ, розпорядження тощо, наприклад: 1. The Under Secretary of Defense (Comptroller) shall provide information to DoD components. 2. Nothing in this Directive shall detract from, nor be construed to conflict with, the authorities and responsibilities of the Combatant Commanders [3, с. 64]. Також доволі характерним для англомовних військових нормативних документів $\epsilon$ застосування модальності облігатива, наприклад: In applying this standard, commanders and managers must take account of the mission [3, c. 64].

Загальновживані дієслова, що входять до складу військової лексики, набувають специфічних значення (наприклад: to detail (for duty) - призначати в наряд; to develop (a position) - розвідувати оборону; to mount (an attack) - переходити в наступ). Попереднє вивчення саме таких значень особливо важливо, тому що не завжди можна зрозуміти значення згаданих вище словосполучень поза військовим контекстом.

Військові документи наповнені спеціальною термінологією, яка відноситься як безпосередньо до військової справи, так і до різних галузей техніки, яка використовується в армії. Ніякі норми живої розмовної мови й у більшості своїй професіоналізми, які часто виступають під терміном «військовий сленг» і які дуже широко використовуються в живому спілкуванні солдатів між собою, не використовуються в офіційних документах. Більше того, оскільки збройні сили та їх складові частини утворюють певні «субкультури або соціальні групи», які «щоденно набувають спільний досвід і навіть формують спільний світогляд», тому від них «можна очікувати спільного мовлення» $[10$, с. 126]. Саме наявність військової лексики слугує першим і досить надійним критерієм, що дає змогу віднести те чи інше повідомлення до професійного мовлення у військовій сфері, тобто кваліфікувати його як військовий текст.

На основі аналізу наукових праць $[1 ; 4 ; 6 ; 7]$ у досліджуваній сфері військову лексику в англійській мові поділяємо на такі дві групи:

1. Військово-прикладну термінологію, що охоплює:

a) офіційну/статутну термінологію (наприклад, barreled weapon (стволова зброя);

б) нестатутну термінологію, яка вживається в усному мовленні військовослужбовців і в деяких 
видах військової літератури, але не є офіційно прийнятою (наприклад, firing bomb mortars (бомбомет)).

2. Емоційно забарвлені лексичні одиниці, які, як правило, $є$ стилістичними синонімами відповідних військових термінів (наприклад, leatherneck (морський піхотинець), up-hill struggle (важкий бій); Doom's Day weapon (термоядерна зброя); cloak and dagger service (секретна служба); silent service (підводний флот)) [4, с. 56].

Варто зазначити, що один і той же термін може мати в США і Сполученому Королівстві різні значення. Наприклад, general staff у США - це загальна частина штабу, яка входить до складу штабу сухопутних військ, що носить назву Army Staff (слово Army, незважаючи на уявну простоту, частіше перекладається не як «армія», а як сухопутні війська), а в Сполученому Королівстві - оперативно-розвідувальна частина штабу; «міністр оборони» в США - Secretary of Defense, а в Сполученому Королівстві - Defence Minister. Слово troop щодо армії Сполученого Королівства варто розуміти як взвод, а для армії США воно відповідає поняттю розвідувальної роти. Squadron для армії Сполученого Королівства варто розуміти як роту, а для армії США - розвідувальний батальйон. Існують терміни, які вживається лише в США (Chief of Staff - начальник оперативного штабу).

У сучасній англійській мові військової сфери триває процес оновлення та поповнення іiі лексичного складу. Так, з'являються нові терміни, пов'язані зі зміною військової тактики і стратегії, оперативного військового мистецтва та стрімким розвитком нових технологій (наприклад, area defense - позиційна оборона укріпленого району; nuclear safety line - зона, яка не порушується ядерним ударом; spoiling attack - контратака; limey - британське військове судно; squarebashing - муштра; whirlybird - гвинтокрил; tent peg - кілок для намету; beltway bandit - колишній держслужбовець; fratricide - ураження своїх військ; shock and awe - військова доктрина США $[9$, c. $23-24])$.

Неминучим видається й зворотний процес: низка термінів виходить 3 ужитку й залишається лише в термінологічних словниках певного історичного періоду. У деяких випадках терміни залишаються в мові, але їх значення 3 часом змінюється. Наприклад, слово blockbuster, яке за часів Другої світової війни позначало a large bomb used to demolish extensive areas (as a city block) (потужний вибуховий пристрій для руйнування великих районів (наприклад, міського кварталу), а в сучасному словнику має таке визначення: a book or film that is very good or successful (книга або фільм, що мають великий успіх). Поява нових значень уже відомих термінів обумовлена найчастіше зміною політичної ситуації у світі, а також науково-технічним розвитком.

Загальновідомо, що найбільш бурхливе зростання кількості нових термінів і зміна вже наявних відбувається під час активізації суспільного життя, а саме під час воєн, революцій, етнічних і релігійних конфліктів. Також певний вплив на формування й розвиток системи військової термінології чинять не тільки фактори науковотехнічного прогресу, а й використання військових термінів поза спеціальним контекстом - політичними діячами в промовах і виступах, журналістами в засобах масової інформації та в приватних бесідах неспеціалістів. Так, побачивши в тексті газетної статті слова air raid, friendly fire, germ warfare, можна зробити висновок про використання автором військових термінів. Разом із тим ці лексичні одиниці включено до словника загальної мови Longman Dictionary of Contemporary English, вони мають тлумачення, які схожі за змістом з визначеннями, що містяться в спеціальному словнику Campaign Dictionary of Military Terms.

Ще однієюхарактерноюрисоювійськовоїтерміносистеми є наявність великої кількості скорочень (складники абревіатури: comsat - communication satellite, stanag - standardization agreement; ініціальні абревіатури: EAGLE - Elevation Angle Guidance Landing Equipment; мішані абревіатури: Univac-universal automatic computer).

Висновки й перспективи подальших розробок. Отже, сучасна англомовна військова фахова мова інтенсивно розвивається та вдосконалюється, відображаючи стан військової науки. У силу багатогранності військових знань аналізована фахова мова характеризується міждисциплінарністю. Військова лексика, охоплюючи військово-прикладну термінологію та емоційно-забарвлені лексичні одиниці, характеризується чіткістю, лаконічністю й функціонує для обслуговування сфери військової діяльності, актуалізуючись в інтрапрофесійних жанрах (військовій публіцистиці, військово-науковій комунікації, військово-дидактичній комунікації та документах регулятивного характеру, які включають настанови, інструкції, накази, команди, розпорядження тощо).

Перспективу подальших розвідок у цьому напрямі вбачаємо у вивченні шляхів перекладу англомовної військово-прикладної термінології засобами української мови.

\section{ЛІТЕРАТУРА}

1. Василенко Д.В. Військова лексика англійської мови XX - початку XXI століття. Горлівка : Вид-во ГДПІІМ, 2009. 220 с.

2. Гарбовский Н., Мишкуров Э.Н. Военный перевод в современном мире. Вестник 
Московского университета. Серия 22 «Теория перевода». 2010. № 2. С. 16-41.

3. Дуброва Ю.Ю. Особенности военного дискурса. Вестник МГЛУ. Серия «Языкознание». 2013. № 5 (665). С. 59-68.

4. Іграк К.Ю. Емоційно забарвлені елементи військової лексики. Науковий вісник ПНПУ ім. К.Д. Уиинського. Серія «Лінгвістичні науки». 2017. № 25. С. 55-59.

5. Лисичкіна I.O. Іміджеформувальні чинники військового дискурсу. Науковий вісник кафедри ЮНЕСКО Київського начіонального лінгвістичного університету. Серія «Філологія, педагогіка, психологія». 2011. Вип. 22. С. 36-39.

6. Навальна М., Калужинська Ю. Актуалізація лексем на позначення військових дій, процесів та станів. Психолінгвітика/Psycholinguistics. 2018. № 24 (2). C. 218-235.

7. Погонець В.В. Номінації сучасної військової техніки в англійській мові. Наукові записки Національного університету «Острозька академія». Серія «Філологічна». 2017. Вип. 67. С. 225-228.

8. Ayto J. Twentieth Century Words. Oxford University Press, 1999. 626 p.

9. Chaloupský L.A. Sociolinguistic Interpretation of Military Slang and Vernacular Expressions. Brno, 2005. $174 \mathrm{p}$.

10. Murray T.E. The Language of Naval Fighter Pilots. American Speech. 1986. Vol. 61. № 2. P. $121-129$.

11. Silkett W.A. Words of War. Military Affairs. 1985. Vol. 49. № 1. P. 13-16.

\section{REFERENCES}

1. Vasilenko, D. V. (2009). Military vocabulary of the English language XX - early XXI century [Viiskova leksyka angliiskoii movy XX - pochatku XXI stolittia]. Horlivka: GDPIIM Publishing House.
2. Garbovsky, N., Mishkurov, E. N. (2010). Military translation in the modern world [Voiennyi perevod $\mathrm{v}$ sovremennom mire]. Bulletin of Moscow University. Series 22. Translation theory, 2, 16-41.

3. Dubrova, Yu.Yu. (2013). Features of military discourse [Osobennosti voiennogo diskursa]. Bulletin of the Moscow State Linguistic University. Linguistics, 5(665), 59-68.

4. Player, K.Yu. (2017). Emotionally colored elements of military vocabulary [Emotsiino zabarvleni elementy viiskovoii leksyky]. Scientific Bulletin of the South Ukrainian National Pedagogical University named after K.D. Ushinsky. Linguistic sciences, 25, 55-59.

5. Lysychkina, I. O. (2011). Image-forming factors of military discourse [Imidzheformuvalni chynnyky viyskovokho dyskursu]. Scientific Bulletin of the UNESCO Department of Kyiv National Linguistic University. Philology, pedagogy, psychology, 22, 36-39.

6. Navalna, M., Kaluzhynska, Y. (2018). Actualization of tokens to denote military actions, processes and states [Aktualizatsiia leksem na poznachennia viiskovykh dii, protsesiv ta staniv]. Psycholinguistics, 24(2), 218-235.

7. Pogonets, V. V. (2017). Nominations of modern military equipment in English. Scientific notes of the National University "Ostroh Academy». Philological series, 67, 225-228.

8. Ayto, J. (1999). Twentieth Century Words. Oxford University Press.

9. Chaloupský, L. A. (2005). Sociolinguistic Interpretation of Military Slang and Vernacular Expressions. Brno.

10. Murray, T. E. (1986). The Language of Naval Fighter Pilots. American Speech, 61(2), 121-129.

11. Silkett, W. A. (1985). Words of War. Military Affairs, 49(1), 13-16. 